\title{
MASA DEPAN PASAR MODAL SYARIAH DI INDONESIA
}

\author{
NUR KHAIRUNNISA \\ Jurusan Perbankan Syariah, Fakultas Ekonomi dan Bisnis Islam \\ Universitas Islam Negeri Alauddin Makassar \\ E-mail : khairunnisanur52@gmail.com
}

\begin{abstract}
In improving Indonesia's economic development, one of the most influential is investment. In the investment sector, there are various kinds of instruments used to encourage the rate of economic growth, one of which is in the capital market sector. For the Indonesian population, which in fact is a Muslim majority, not a few are still questioning investment activities in this capital market. Therefore, the Islamic capital market was born which is a capital market or (place) that applies sharia principles in economic transactions and is free from all elements that are forbidden by Islamic law, such as usury, maisir (gambling), and gharar (ambiguity), and speculation. and includes the types of goods traded which do not violate Islamic law. Currently, the development of the Islamic capital market is very significant and continues to increase every year. In statistical data managed by the OJK, Islamic stocks have increased from the number of listed sharia securities recorded in 2013 of 328 to 445 in 2019. Likewise, sharia bonds and sharia mutual funds are also continuing to grow.
\end{abstract}

Keywords : Economy, Capital, Market, Sharia

\begin{abstract}
ABSTRAK
Dalam meningkatkan pembangunan perekonomian Indonesia, salah satunya yang berpengaruh besar adalah investasi. Didalam sektor investasi terdapat berbagai macam instrumen yang digunakan untuk mendorong laju pertumbuhan ekonomi, salah satunya adalah pada sektor pasar modal. Bagi penduduk Indonesia yang
\end{abstract}


notabennya mayoritas Muslim, tidak sedikit juga yang masih mempertanyakan kegiatan investasi dalam pasar modal ini. Oleh karena itu, lahirlah pasar modal syariah yang merupakan pasar modal atau (tempat) yang menerapkan prinsip syariah dalam bertansaksi ekonomi dan terbebas dari semua unsur yang diharamkan syariat islam, seperti harta riba, maisir (judi), dan gharar (ambiguitas), serta spekulasi dan termasuk jenis barang yang di perdagangkan yang sifatnya tidak melanggar hukum islam. Saat ini perkembangan pasar modal syariah sangat signifikan dan terus meningkat setiap tahunnya. Pada data statistik yang dikelola OJK, saham syariah mengalami peningkatan dari jumlah daftar efek syariah yang tercatat tahun 2013 sebesar 328 naik menjadi 445 ditahun 2019. Begitu pun dengan obligasi syariah dan reksadana syariah yang juga terus berkembang.

\section{Kata Kuci : Ekonomi, Modal, Pasar, Syariah}

\section{A. Pendahuluan}

Dalam meningkatkan pembangunan perekonomian Indonesia, salah satunya yang berpengaruh besar adalah investasi. Sarana investasi dibutuhkan untuk menangani sebagian permasalahan perekonomian Indonesia. Didalam sektor investasi terdapat berbagai macam instrumen yang digunakan untuk mendorong laju pertumbuhan ekonomi, salah satunya adalah pada sektor pasar modal (Nurafiati, 2019).

Selain perbankan yang merupakan penyedia modal untuk masyarakat, pasar modal juga merupakan wadah bagi pihak yang kelebihan modal dan pihak yang membutuhkan modal. Selain itu, pasar modal juga berfungsi sebagai pencairan kepemilikan saham dalam suatu perusahaan. Dengan berbagai manfaat dan peran pasar modal menjadikan instrumen ini semakin berkembang khususnya di Indonesia sendiri. 
Bagi penduduk Indonesia yang notabennya mayoritas Muslim, tidak sedikit juga yang masih mempertanyakan kegiatan investasi dalam pasar modal ini. Oleh karena itu, lahirlah pasar modal syariah yang menjawab keraguan sebagian masyarakat dan telah disahkan pada tahun 2003. Pasar modal syariah ini juga turut mewarnai kebangkitan Islam di bidang ekonomi dengan adanya transaksi dan kegiatan ekonomi berdasarkan prinsip syariah. Dari sisi dasar hukum pasar modal syariah didasarkan pada fatwa Dewan Syariah Nasional-Majelis Ulama Indonesia (DSNMUI) dan juga diatur dalam UU No.8 tahun 1995 tentang Pasar Modal. Kegiatan dalam UU tersebut bisa dilakukan sesuai prinsip syariah maupun konvensional (Toha et al., 2020).

Ada beberapa alasan yang mendasari pentingnya keberadaan sebuah pasar modal syariah, yakni pertama, harta yang melimpah jika tidak diinvestasikan pada tempat yang tepat sangat disayangkan. Selama ini harta yang melimpah banyak diinvestasikan di negara-negara non-Muslim. Kedua, fuqaha dan pakar ekonomi Islam telah mampu membuat surat-surat berharga yang berlandaskan Islam sebagai alternatif bagi surat-surat berharga yang beredar dan tidak sesuai dengan hukum Islam. Ketiga, melindungi para penguasa dan pebisnis Muslim dari ulah para spekulan ketika melakukan investasi atau pembiayaan pada surat-surat berharga. Keempat, memberikan tempat bagi lembaga keuangan Islam dan ilmu-ilmu yang berkaitan dengan teknik perdagangan. Sekaligus melakukan aktivitas yang sesuai dengan syariah (Khalisah, 2019). Berdasarkan hal tersebut, dalam jurnal ini penulis bermaksud mengulas bagaimana perkembangan pasar modal syariah di Indonesia. 


\section{B. PEMBAHASAN}

\section{Pengertian dan Sejarah Pasar Modal Syariah}

Secara umum pasar modal syariah yaitu suatu pasar modal atau (tempat) yang menerapkan prinsip syariah dalam bertansaksi ekonomi dan terbebas dari semua unsur yang diharamkan syariat islam, seperti harta riba, maisir (judi), dan gharar (ambiguitas), serta spekulasi dan termasuk jenis barang yang di perdagangkan yang sifatnya tidak melanggar hukum islam. Sehingga segala aspek yang ada dan yang dijalankan berdasarkan prinsip dalam kaidah syariah, oleh karna itu di namakan pasar modal syariah (Suhender, 2020).

Dalam pasar modal syariah instrumen yang boleh diperjualbelikan adalah instrumen pasar modal yang memenuhi prinsip-prinsip Islam, adapun yang menjadi instrumen pasar modal syariah adalah:

a. Saham Syariah

Saham syariah adalah saham yang tidak bertentangan dengan prinsipprinsip Islam di pasar modal. Bursa saham Islami harus diatur berdasarkan prinsip islam melalui partisipasi ekuitas. Kepemilikan bursa saham akan menjadi milik pemegang saham di bursa saham. Untuk mencapai berfungsinya bursa efek, pemegang sahamnya tidak akan diizinkan untuk berpartisipasi dalam perdagangan dan tidak akan diizinkan menjadi mitra pemain lain di pasar saham. Pemegang saham ini dapat berupa institusi maupun individu. Para pemegang saham harus mematuhi semua hukum berdasarkan syariah. Bursa saham akan dikenakan tata kelola perusahaan berdasarkan ketentuan Islam atau kode Islam (Huda, 2016). 
b. Sukuk

Sukuk (surat berharga syariah)/obligasi syariah dianggap sebagai instrumen keuangan syariah yang dibuat untuk pembiayaan jangka menengah dan panjang karena beberapa keterbatasan yang ada dalam sistem keuangan syariah, sehingga kurangnya penggunaan obligasi umum. Instrumen ini sangat mirip dengan obligasi biasa; Namun, ada beberapa perbedaan juga antara keduanya dan dalam beberapa kasus mereka menanggung karakteristik saham. Hal ini menyebabkan Sukuk dianggap sebagai jenis instrumen keuangan hybrid. Di luar sistem keuangan Islam, instrumen hybrid dianggap sebagai salah satu jenis sekuritas yang berlaku dan umum. Instrumen ini dibagi menjadi beberapa kategori, yang masing-masing memiliki karakteristik obligasi dan saham (Muklis, 2016).

c. Reksadana Syariah

Reksa Dana Syariah adalah dana investasi yang diatur oleh persyaratan hukum Syariah dan prinsip-prinsip agama Islam. Dana yang sesuai syariah dianggap sebagai jenis investasi yang bertanggung jawab secara social. Dana yang sesuai syariah memiliki banyak persyaratan yang harus dipatuhi. Beberapa persyaratan untuk dana yang sesuai syariah termasuk pengecualian investasi yang memperoleh sebagian besar pendapatan mereka dari penjualan alkohol, produk daging babi, pornografi, perjudian, peralatan militer atau senjata. Karakteristik lain dari dana yang sesuai Syariah termasuk dewan Syariah yang ditunjuk, audit Syariah tahunan dan memurnikan jenis 
pendapatan tertentu yang dilarang, seperti bunga, dengan menyumbangkannya untuk amal (Zolfaghari, 2019).

Sejarah pasar modal syariah di Indonesia sendiri dimulai dengan diterbitkannya salah satu instrumen pasar modal syariah yaitu reksadana syariah oleh PT. Danareksa Investment Management, pada tanggal 3 Juli 1997. Selanjutnya, pada tanggal 3 Juli 2000 Bursa Efek Indonesia bekerja sama dengan PT. Danareksa Investment Management meluncurkan Jakarta Islamic Index (JII) yang melisting 30 saham berbasis syariah.

Operasional pasar modal syariah di Indonesia diluncurkan secara resmi pada tanggal 14 Maret 2003, bersamaan dengan penandatanganan Memorandum of Understanding (MoU) antara Badan Pengawas Pasar Modal dan Lembaga Keuangan (Bapepam-LK) dengan Dewan Syariah NasionalMajelis Ulama Indonesia (DSN-MUI). Instrumen pasar modal syariah lainnya berupa obligasi syariah muncul dengan diterbitkannya obligasi syariah PT Indosat Tbk. di awal September 2002. Pada tahun 2004 untuk pertama kalinya terbit pula obligasi syariah ijarah dan tahun 2006 terbit reksadana syariah.

Selain JII, berdasarkan keputusan Bapepam-LK berkoordinasi dengan DSNMUI dikeluarkan Daftar Efek Syariah (DES) yang per 30 November 2007 mendaftarkan 20 obligasi syariah dan 172 saham syariah. Dengan Demikian, dari sejarahnya di atas, pasar modal syariah di Indonesia memiliki diferensiasi antara lain: (1) adanya saham-saham syariah, (2) adanya JII, (3) keberadaan obligasi syariah, (4) keberadaan reksadana syariah, dan (5) adanya DES (Ridwansyah, 2020). 


\section{Perkembangan Pasar Modal Syariah di Indonesia}

Dinamika Pasar modal syariah di Indonesia secara langsung atau tidak langsung dapat diukur dari fluktuasi grafik JII. Sejak diluncurkannya JII hingga dua bulan pertama tahun 2008, Pasar modal syariah di Indonesia secara umum menunjukkan pertumbuhan yang positif. Dimulai dengan angka dasar 100, pada penutupannya di tahun 2005 JII telah mencapai angka 199,749. Lalu pada penutupan tahun 2006, JII telah mencapai angka 311,251 meningkat 55,8\% dari tahun sebelumnya. Lebih hebat lagi pada penutupan tahun 2007 dan awal 2008, JII sempat menembus level 500.

Pertumbuhan positif JII dalam besaran yang membanggakan itu menimbulkan ekspektasi yang besar bagi berbagai kalangan untuk berinvestasi pada saham syariah. Tidak hanya pada saham syariah, para investor juga berinvestasi pada obligasi dan reksadana syariah. Para ekonom syariah Indonesia malahan memandang prospek di obligasi syariah masih sangat luas dan besar, karena obligasi syariah baru diterbitkan untuk dua akad, yaitu mudarabah dan ijarah.

Akan tetapi, pertumbuhan yang positif pada Pasar modal konvensional dan Pasar modal syariah di Indonesia belum tentu menunjukkan bahwa kemakmuran bersama telah menaungi seluruh rakyat Indonesia. Kenyataannya justru menunjukkan bahwa kesenjangan ekonomi antara si kaya dan si miskin semakin membesar. Hal ini karena para pelaku pasar modal hanya meliputi jumlah manusia yang sangat kecil dibandingkan keseluruhan manusia 
Indonesia. Akan tetapi, jumlah manusia yang kecil itu menggulirkan investasi yang fantastis, dapat mencapai nominal trilyunan rupiah setiap harinya.

Di samping itu, nilai dasar Sistem Ekonomi Islam, yaitu keseimbangan, keadilan, dan kepemilikan oleh ahlinya, belum merasuki dinamika dan tekad para pelaku pasar di Pasar modal syariah. Akibatnya, Pasar modal syariah masih pekat diwarnai spekulasi serta sikap egois para pelaku pasarnya yang selalu tergesa-gesa mengejar laba dan melupakan sikap saling tolongmenolong. Dengan kata lain, Pasar modal syariah masih rapat mengikuti Pasar modal konvensional yang mengedepankan kapitalisme dan sikap materialis.

Kondisi tersebut dapat menjadi pelajaran berharga bahwa penerapan prinsip syariah haruslah disikapi secara sungguh-sungguh dengan meneladani karakter seimbang dan adil sebagai nilai dasarnya. Dengan demikian watak spekulan dan egois ingin untung dengan cepat, tidak lagi mewarnai operasional Pasar modal syariah di Indonesia. Demikian pula, tidak salah untuk selalu mempertimbangkan kembali berbagai akad dan praktek di dalam Pasar modal syariah. Jangan-jangan mekanisme yang langsung memutar uang masyarakat di sektor riil justru lebih baik dibandingkan memutar uang itu di pasar keuangan termasuk pasar modal (Munawiroh \& Rumawi, 2020).

Sedangkan perkembangan pasar modal syariah dalam jurnal yang ditulis oleh (Toha et al., 2020) menyatakan bahwa perkembangan pasar modal syariah dapat dilihat dari sisi instrumentnya. Jika instrument- instrumen itu berkembang dengan sangat signifikan maka kinerja pasar modal syariah juga dapat dikatakan baik. 
Saham syariah merupakan instrumen pasar modal syariah lainnya yang kinerjanya lebih unggul dibandingkan saham konvensional. Hal ini dibuktikan dengan melihat statistik perkembangannya sejak tahun 2013 hingga tahun 2019 yang terus meningkat. Pada tahun 2013 periode pertama Daftar Efek Syariah sebesar 302 dan periode kedua meningkat hingga 328. Sedangkan ditahun 2019 periode pertama tercata 408 dan periode kedua mencapai 445 .

Reksadana syariah juga merupakan portofolio pasar modal syariah yang perkembangannya terus mengalami peningkatan dari tahun 2015 hingga 2019. Tercatat dalam data statistik pasa modal syariah yang dikelola Direktorat Pasar Modal Syariah-Otoritas Jasa Keuangan, pada tahun 2015 dengan NAB sebesar Rp 10 miliar hingga tahun 2019 mencapai Rp 53,735 miliar dengan jumlah reksadana syariah yang beredar sebanyak 265 .

Obligasi syariah atau yang dikenal dengan istilah Sukuk berasal dari bahasa Arab Sakk, yang artinya sertifikat atau bukti kepemilikan. Sedangkan Menurut Peraturan Bapepam-LK Nomor IX.A.13 sukuk adalah efek syariah berupa sertifikat atau bukti kepemilikan yang bernilai sama dan mewakili bagian yang tidak tertentu (tidak terpisahkan atau tidak terbagi atas aset berwujud, nilai atas aset berwujud, jasa, asset proyek, dan kegiatan investasi yang telah ditentukan. Perkembangan sukuk naik turun. jumlah sukuk outstanding pada tahun 2019 sebesar 143 dengan nilai outstanding yang mencapai Rp 29,84 triliun. Melihat dari perkembangan instrument pasar modal diatas, secara garis besar pasar modal syariah di Indonesia bisa dibiliang berkembang. 


\section{KESIMPULAN}

Perkembangan pasar modal syariah dapat dilihat dari perkembangan instrumentnya diantaranya saham syariah, obligasi syariah dan reksadana syariah. Ketiga instrumen ini juga terus mengalami peningkatan meskipun tetap saja konvensional lebih unggul tetapi tidak mengurangi kinerja pasar modal syariah dan minat para investor yang memilih instrument pasar modal syariah. Pada dasarnya pasar modal syariah tidak memiliki Undang-Undang khusus dan masih mengacu pada UU No. 8 Tahun 1995 tentang Pasar Modal. Tetapi regulasi pasar modal syariah ini di dukung dengan fatwa yang dikeluarkan oleh DSN-MUI yang membuktikan kepada masyarakat bahwa transaksi pasar modal syariah sudah sesuai dengan prinsip syariah.

\section{DAFTAR PUSTAKA}

Huda, N. (2016). Perkembangan Pasar Modal Syariah Di Indonesia. Junal Ekonomi Yarsi, 3(5), 63-77.

Khalisah, N. (2019). Pasar Modal Syariah (Ketika "Syariah” Hanya Sebuah Kata). IMANENSI: Jurnal Ekonomi, Manajemen Dan Akuntansi Islam, 2(1), 12-17. Muklis, F. (2016). Perkembangan dan Tantangan Pasar Modal. Al Masraf, 1(1), 6774.

Munawiroh, A., \& Rumawi. (2020). Melacak Investasi Syariah: Studi Perkembangan Sukuk Bagi Pasar Modal Syariah di Indonesia. Kertha Semaya, $8(10), 1551-1565$.

Nurafiati, N. (2019). Perkembangan Pasar Modal Syariah Dan Kontribusinya 
Terhadap Pertumbuhan Ekonomi Di Indonesia. Inklusif (Jurnal Pengkajian Penelitian Ekonomi Dan Hukum Islam), 4(1), 65.

Ridwansyah, M. (2020). Pasar Modal Syariah ( PMS ) Di Indonesia. 2(2019), 91107.

Suhender, F. R. (2020). Konsep Pasar Modal Syariah Beserta Perkembangannya di Indonesia. Jurnal Syntax Admiration, 1(7), 304-314.

Toha, M., Manaku, A. C., \& Zamroni, M. A. (2020). Perkembangan Dan Problematika Pasar Modal Syariah Di Indonesia. Jurnal Al-Tsaman, 2(1), $135-144$.

Zolfaghari, P. (2019). An Introduction to Islamic Securities (Sukuk). 19(1), 21-30. 